\title{
Differential Cultivars and Criteria for Evaluating Resistance to Rhizoctonia solani in Seedling Brassica oleracea
}

\author{
Anthony P. Keinath, Associate Professor, Clemson University, Department of Plant Pathology \& Physiology, \\ Coastal Research \& Education Center, and Mark W. Farnham, Research Geneticist, USDA, ARS, U.S. Vegetable \\ Laboratory, Charleston, SC 29414
}

\begin{abstract}
Keinath, A. P., and Farnham, M. W. 1997. Differential cultivars and criteria for evaluating resistance to Rhizoctonia solani in seedling Brassica oleracea. Plant Dis. 81:946-952.

Growth-room and field experiments were conducted to develop methods of studying resistance in Brassica oleracea crops to Rhizoctonia solani anastomosis groups (AG) 2-1 and 4, causal agents of wirestem. Seedlings of 12 cultivars (3 each of broccoli, cauliflower, cabbage, and collard) at the four- to five-leaf stage were transplanted to trays in a growth room and covered with steamed soil infested with cornmeal-sand cultures or sclerotia of $R$. solani or to fumigated field plots infested with sclerotia. The percent healthy, diseased, and dead plants was assessed every 3 to 5 days for 2 weeks in the growth room and for 3 weeks in field trials. At harvest, plants were dug out with roots intact and rated for wirestem severity. In most experiments, wirestem incidence (percent diseased and dead plants) stabilized within 10 to 14 days after inoculation. Inoculation with cornmeal-sand cultures of both AGs and sclerotia of AG-4 resulted in severe wirestem in all experiments, whereas sclerotia of AG-2-1 were less effective in the growth room and not effective in the field. Percent healthy and surviving (healthy plus diseased) plants, area under the disease progress curve (AUDPC), and wirestem severity all separated the most susceptible from the partially resistant cultivars more consistently than fresh weight of inoculated plants expressed as a percentage of noninoculated plant weight. Wirestem severity and AUDPC were always negatively and significantly $(P \leq 0.01)$ correlated with percent healthy plants. Although genotype by environment interactions were observed, the cauliflower cvs. Snowcone and Snow Crown were severely diseased in all experiments, whereas collard cv. Blue Max was consistently and significantly $(P \leq 0.05)$ less diseased.
\end{abstract}

Additional keywords: Brassica perviridis, cole crops

Rhizoctonia solani Kühn, a ubiquitous soilborne fungal pathogen, reduces emergence of direct-seeded crucifers and stands of both direct-seeded and transplanted crops (pre- and postemergence dampingoff, respectively) $(2,11,12,17,19,27,32)$. Surviving plants, especially in the genus Brassica, may be stunted due to wirestem, which is caused by dark lesions of varying depth on the hypocotyl at or just above the soil line $(11,17,24)$. As a result, yield is reduced, especially for heading types of $B$. oleracea L. (25). R. solani was the most virulent pathogen isolated from diseased $B$. oleracea seedlings in Georgia (27). Two isolates (anastomosis group [AG] not determined) were virulent at low- and hightemperature regimes, whereas a third isolate was virulent only at high temperatures

Corresponding author: A. P. Keinath

E-mail: tknth@clemson.edu

Technical contribution 4253 of the South Carolina Agriculture and Forestry Research System, Clemson University.

Accepted for publication 17 May 1997.

Publication no. D-1997-0620-01R

(C) 1997 The American Phytopathological Society
(32/21 ${ }^{\circ} \mathrm{C}$ day/night). $R$. solani also was the most virulent pathogen isolated from diseased seedling and adult canola (B. napus L. and B. campestris L.) in western Canada $(12,15,32)$. R. solani AG-2-1 was isolated more frequently from seedlings and adult plants, 96 and $69 \%$, respectively, than AG4,4 and $29 \%$, respectively (32). In Georgia, however, only $R$. solani AG-4 was recovered from diseased canola seedlings in a limited survey (2). In South Carolina, R. solani AG-4 and AG-2-1 have been isolated from diseased cabbage and collard seedlings, transplants, and mature plants in commercial fields (A. P. Keinath, personal observations).

As crucifer seedlings age, they begin to express resistance to $R$. solani $(11,23)$. For example, hypocotyls of Sinapis alba cv. Arda, a resistant mustard, and B. napus cv. Midas, a moderately tolerant canola, were more resistant at 3 weeks of age than at 1 week (30). Cuticle thickness in B. napus and $S$. alba was correlated with resistance to $R$. solani AG-2-1. Although $S$. alba and Midas were more resistant than other $B$. napus cultivars, 3-week-old $S$. alba seedlings had a thicker cuticle and were significantly more resistant than 3-week-old $B$. napus seedlings. The role of cuticle thickness in B. oleracea has not been de- termined. Relative to canola, cabbage appears to be more susceptible to wirestem, because a lower inoculum density was required for disease incidence near $100 \%$ (17, 31).

Ogoshi (20) suggested that individual AGs of $R$. solani should be used in germ plasm screening and breeding to improve the chances of successfully identifying useful resistance. Results of screening for resistance to $R$. solani have varied according to the hosts and techniques used. Pisum sativum L. genotypes range from susceptible to moderately resistant to stem rot caused by $R$. solani AG-4 (18). Williams (29) described a procedure using individually grown crucifer seedlings inoculated with maize kernels colonized with $R$. solani. With this inoculation technique, carrot seedlings of different ages differed in susceptibility to crown rot and cavity spot caused by $R$. solani (AG not identified), but two cultivars did not differ (13). A variety of greenhouse and laboratory techniques failed to differentiate radish cultivars resistant and susceptible to $R$. solani AG-4 (8). Although most canola genotypes were susceptible, several lines were resistant to Rhizoctonia (AG-2-1) damping-off and seedling root rot in growth-room and field tests (1). In one of the few reports on B. oleracea, differences in wirestem incidence were observed among 11 cauliflower cultivars, although none were considered resistant (7).

Cultivars of cabbage, collard, and other B. oleracea crops resistant to wirestem would reduce stand losses and reliance on soilapplied fungicides and fumigants to manage this disease. To be useful, cultivars should have resistance to both $R$. solani AG-4 and AG-2-1, because both AGs are present in South Carolina soils planted to cole crops. The objectives of this study were to (i) compare the reproducibility of different $R$. solani inoculum types, (ii) determine which criteria are most useful for measuring the response of $B$. oleracea to inoculation with $R$. solani, and (iii) determine the reaction of different $B$. oleracea cultivars to inoculation with $R$. solani AG-2-1 and AG-4. A preliminary report of this study has been presented (10).

\section{MATERIALS AND METHODS}

Pathogen culture. $R$. solani AG-4 isolate SP1 was obtained from a diseased spinach root in Bamberg County, SC, during 
December 1991 (17). R. solani AG-2-1 isolate RB1 was obtained from a diseased broccoli stem in Charleston County, SC, during November 1992. Both isolates were stored on soil-wheat bran at $-20^{\circ} \mathrm{C}$ (5). Cornmeal-sand (3\% wt/wt) in 250-ml flasks was autoclaved for $1 \mathrm{~h}$ on three successive days. Cultures of $R$. solani on potato dextrose agar (PDA) (7 to 10 days old) were flooded with sterile distilled water and gently scraped to make a mycelial suspension, 5 $\mathrm{ml}$ of which was added to each flask of cornmeal-sand (17). Flasks were incubated at ambient temperatures $\left(22\right.$ to $\left.25^{\circ} \mathrm{C}\right)$ for 1 week. CFU were determined by suspending $0.1 \mathrm{~g}$ of colonized cornmeal-sand in $9.9 \mathrm{ml}$ of sterile distilled water and plating dilutions on one-quarter-strength PDA. Sclerotia were produced on autoclaved green beans (28) and sieved to separate those of 710 to $1,000 \mu \mathrm{m}$ diameter, which were then stored at $4^{\circ} \mathrm{C}$ for 1 to 4 months before use. Germinability of sclerotia older than 1 month was tested before each experiment by placing 100 sclerotia on water agar and counting the number that had germinated after 1 and 2 days.

Growth-room experiments. Seed was sown in a commercial potting mix (Metromix 360, Grace Sierra, Milpitas, CA) in 150 -cell trays in a greenhouse. Seedlings of 12 cultivars (Table 1), 3 each of broccoli, cauliflower, cabbage, and collard at the four- to five-leaf stage were transplanted into 72-cell trays. Stems were covered up to the cotyledons with steamed sandy loam soil infested with $R$. solani. The experiment was a split-plot randomized complete-block design with four replications. The whole-unit treatments were a factorial arrangement of isolate, SP1 and $\mathrm{RB}$, by inoculum, 0.5 to $1.0 \%$ ( $\mathrm{vol} / \mathrm{vol})$ cornmeal-sand cultures and 50 sclerotia per $\mathrm{kg}$ of soil, plus noninfested soil as a control. The subunit treatment was cultivar. Five and ten transplants were used in each replication of the control and the four treatments, respectively. Trays were placed in a growth room held at $26.7^{\circ} \mathrm{C}$ with a 14-h photoperiod. The experiment was performed twice.

The number of healthy, diseased, and dead seedlings was determined four times at 3- to 4-day intervals, beginning 3 days after inoculation. Plants were considered diseased if a purplish-black, sunken lesion was visible on the hypocotyl at the soil line or if leaves were wilted and the plant was stunted $(6,17)$. Plants were considered dead when all leaves had senesced. At 2 weeks after inoculation, live and dead plants were removed from the trays and gently washed with a stream of water to remove adhering soil from roots. Disease severity on stem and roots was rated on a pretransformed scale of 1 to 10 , based on a scale previously developed (17): 1 = no symptoms; 2 = superficial cracking of the stem cortex without discoloration on $<50 \%$ of the stem circumference; $3=$ superficial cracking of the stem cortex with discoloration on $\geq 50 \%$ of the stem circumference; $4=0$ to $<25 \%$ of the stem circumference girdled with a single lesion $\geq 1 \mathrm{~mm}$ deep; $5=25$ to $75 \%$ of the stem circumference girdled $\geq 1 \mathrm{~mm}$ deep; $6=>75$ to $100 \%$ of the stem circumference girdled $\geq 1 \mathrm{~mm}$ deep; $7=$ stem girdled through the endodermis and plant stunted; $8=$ stem girdled through the endodermis and lateral roots absent; $9=$ lower

Table 1. Reaction of 12 Brassica oleracea cultivars to Rhizoctonia solani anastomosis groups (AG) 4 and 2-1 in growth-room experiments ${ }^{\mathrm{u}}$

\begin{tabular}{llcccc}
\hline Crop & Cultivar & \% Healthy & \% Survivors & $\begin{array}{c}\text { Wirestem } \\
\text { severity }^{\mathbf{w}}\end{array}$ & $\begin{array}{c}\text { \% Control } \\
\text { weight }^{\mathbf{x}}\end{array}$ \\
\hline Cauliflower & Snowcone & 17.5 & $56.3 \mathrm{c}^{\mathrm{y}}$ & $7.6 \mathrm{a}$ & $34.5 \mathrm{c}$ \\
& Snow Crown & 14.4 & $59.2 \mathrm{c}$ & $7.6 \mathrm{a}$ & $35.1 \mathrm{c}$ \\
\multirow{3}{*}{ Broccoli } & Arctic & 26.3 & $80.6 \mathrm{ab}$ & $6.7 \mathrm{~b}$ & $57.5 \mathrm{~b}$ \\
& Packman & 19.4 & $66.9 \mathrm{bc}$ & $7.2 \mathrm{ab}$ & $42.8 \mathrm{bc}$ \\
& Viking & 29.4 & $71.9 \mathrm{bc}$ & $6.9 \mathrm{ab}$ & $55.8 \mathrm{~b}$ \\
Cabbage & Eureka & 26.3 & $68.8 \mathrm{bc}$ & $7.0 \mathrm{ab}$ & $59.0 \mathrm{~b}$ \\
& Constanza & 25.0 & $67.5 \mathrm{bc}$ & $6.8 \mathrm{ab}$ & $56.9 \mathrm{~b}$ \\
& Little Rock & 21.9 & $76.9 \mathrm{ab}$ & $6.9 \mathrm{ab}$ & $55.1 \mathrm{~b}$ \\
Collard & Bravo & 23.8 & $78.1 \mathrm{ab}$ & $6.7 \mathrm{~b}$ & $50.2 \mathrm{bc}$ \\
& Vates & 22.5 & $67.5 \mathrm{bc}$ & $7.1 \mathrm{ab}$ & $52.8 \mathrm{~b}$ \\
& NC landrace & 22.5 & $69.4 \mathrm{bc}$ & $7.0 \mathrm{ab}$ & $59.4 \mathrm{~b}$ \\
LSD $_{0.05}$ & Blue Max & 30.2 & $93.1 \mathrm{a}$ & $5.7 \mathrm{c}$ & $85.2 \mathrm{a}$ \\
\hline
\end{tabular}

"All values are means of AG-4 and AG-2-1 treatments, because there was no cultivar by isolate interaction.

${ }^{\mathrm{v}}$ Percent surviving plants at harvest $=$ (number of healthy + number of diseased plants) $/($ total number of plants).

${ }^{\mathrm{w}}$ Wirestem severity at harvest was rated on a scale of 1 to 10 , where $1=$ no disease and $10=$ plant completely rotted.

${ }^{\mathrm{x}}$ Percent control weight $=$ weight of inoculated plants in each replication/mean weight of noninoculated plants of the same cultivar across replications.

${ }^{y}$ Means within a column followed by the same letter are not significantly different according to Fisher's protected least significant difference test, $\alpha=0.05$.

${ }^{\mathrm{z}}$ Not significantly different.

stem decayed through the stele and taproot absent; and $10=$ entire plant decayed. Fresh weight of all plants was measured.

Field experiments. Field plots were established at the Coastal Research and Education Center, Charleston, SC, in Dupont very fine sandy loam soil (an Aquult). Soil

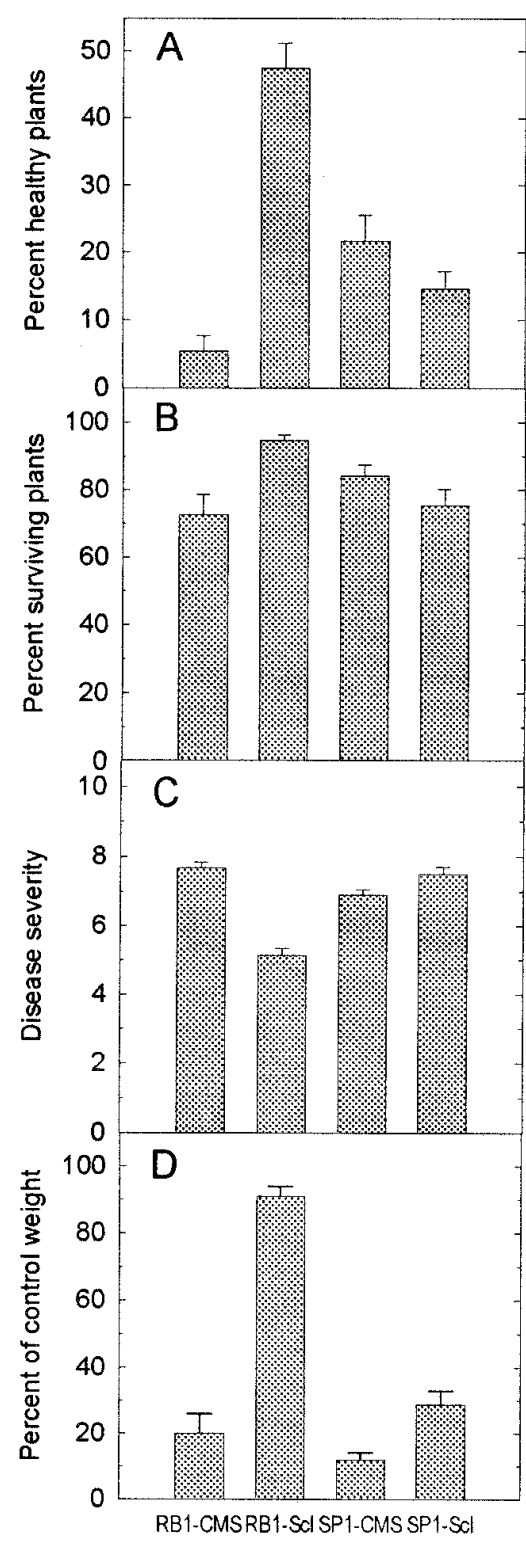

Fig. 1. Criteria used to assess the reaction of Brassica oleracea cultivars to inoculation with Rhizoctonia solani anastomosis group (AG) 2-1 (isolate RB1) or 4 (isolate SP1) in growth-room experiments. Seedlings were inoculated with $1.0 \%$ (RB1) or $0.5 \%$ (SP1) infested cornmeal-sand or 50 sclerotia per $\mathrm{kg}$ of soil. (A) Percent healthy plants; (B) percent healthy and diseased plants; (C) severity on a scale of 1 (no symptoms on hypocotyl) to 10 (plant decayed); and (D) fresh weight of inoculated plants as a percentage of control plant weight were assessed at seedling harvest 2 weeks after inoculation. Values are the means for 12 cultivars, because there were no interactions between cultivar and AG or inoculum. Vertical error bars show one standard error of the mean. 
was fumigated by injecting $121 \mathrm{~kg}$ of $98 \%$ methyl bromide- $2 \%$ chloropicrin per ha 15 $\mathrm{cm}$ deep and covering with black polyethylene mulch for 20, 18, and 12 days in 1994, 1995, and 1996, respectively, to reduce the level of indigenous $R$. solani. Before planting, mulch was removed, and plots were fertilized with $\mathrm{N}$ at $168 \mathrm{~kg}, \mathrm{P}$ at $75 \mathrm{~kg}$, and $\mathrm{K}$ at $140 \mathrm{~kg} / \mathrm{ha}$. The experimental design was a split plot with four replications. The whole-plot treatment was isolate (SP1, $\mathrm{RB} 1$, or noninfested), and the subplot treatment was cultivar (the same 12 cultivars used in the growth-room experiments). Whole plots were single raised beds spaced $1.8 \mathrm{~m}$ apart. Whole plot treatments were separated by $1.5 \mathrm{~m}$ within beds. Each subplot was $0.9 \mathrm{~m}$ wide and $1.5 \mathrm{~m}$ long, with two rows of transplants spaced $30 \mathrm{~cm}$ apart. Transplants at the four- to five-leaf stage were spaced $15 \mathrm{~cm}$ apart within rows, and stems were covered with soil up to the cotyledons. In 1994, sclerotia of SP1 and RB1 were spread uniformly over the surface of each infested

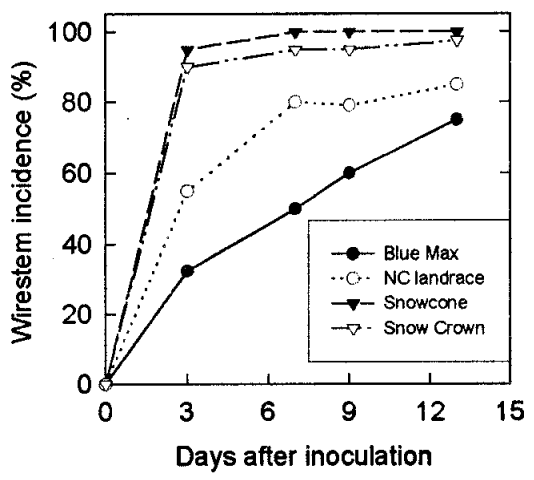

Fig. 2. Wirestem progression (percent diseased and dead plants) on susceptible cauliflower (cvs. Snowcone and Snow Crown) and moderately resistant collard (cvs. Blue Max and a NC landrace) plants in growth-room tests. Seedlings were inoculated with 50 sclerotia of Rhizoctonia solani anastomosis group 4 per $\mathrm{kg}$ of soil. Each data point is the mean of eight observations (four replications in two tests). subplot at $50 / \mathrm{kg}$ of soil (based on a soil weight of $2.2 \times 10^{6} \mathrm{~kg}$ of soil per ha to a depth of $15 \mathrm{~cm}$ ) and incorporated $10 \mathrm{~cm}$ deep with a rake (17). Plots were raked smooth before transplants were set. In 1995 and 1996, the inoculum density was lowered to 25 sclerotia per $\mathrm{kg}$ of soil because of the high level of disease observed in 1994. To reduce the amount of inoculum needed, sclerotia of SP1 were spread uniformly in a 7.5-cm-wide band over each of the two rows in each infested subplot and incorporated $7.5 \mathrm{~cm}$ deep with a hand-held cultivator ("garden weasel"). Transplants were set on 12 August and 21 October 1994, 18 October 1995, and 29 April 1996. Mustard (B. perviridis L.H. Bailey cv. Tendergreen) was included as a resistant cultivar in 1995 and 1996.

Plants were rated as healthy, diseased, or dead based on visual symptoms as described for growth-room experiments at 3 , $7,10,14$, and 20 days after transplanting in 1994 and at $5,8,11,14$, and 19 or 16 days after transplanting in 1995 and 1996, respectively. The initial rating was delayed in 1995 and 1996 because disease progressed slower at the lower inoculum density. Plants were not harvested in 1994, so disease progression could be assessed throughout the growing season. Plants were harvested on 6 November 1995 (19 days after transplanting) and 15 May 1996 (16 days after transplanting), based on the rate of host development. Wirestem severity and fresh weight were determined as described previously for growth-room experiments. For selected plots, stem segments with lesions were cut, surface-disinfested in $0.5 \% \mathrm{NaOCl}$ solution for $30 \mathrm{~s}$, rinsed in sterile distilled water, and placed on water agar plus $100 \mathrm{mg}$ of streptomycin sulfate per liter. Hyphae growing from diseased tissue were transferred to PDA to verify identification as $R$. solani. Hyphae of randomly selected colonies were stained with $3 \% \mathrm{KOH}$ and alkaline safranin $\mathrm{O}$ to determine the number of nuclei per cell (3).
Statistical analysis. Analysis of variance was performed with PROC GLM of SAS (release 6.10, SAS Institute Inc., Cary, NC). All data sets were tested for equality of variance and normality before analysis; in general, transformations were not necessary. Data from individual trials were pooled and analyzed together when error variances were equal according to two-tailed $F$ tests (26). Area under the disease progress curve (AUDPC) was calculated from visual disease assessments with standard iterative procedures (22). Changes in disease incidence (percent diseased plus dead plants) over the five ratings were compared with a repeated measures analysis of variance; Helmert contrasts of canonical coefficients were calculated to determine which incidence readings from a given date differed significantly from subsequent readings or when disease incidence plateaued (21). Plant weight was reported as percent control weight (weight of inoculated plants in each replication divided by mean weight of control plants of that particular cultivar over all replications) to account for differences in growth rate among cultivars. Treatment and cultivar means were compared with least squares means $t$ tests and Fisher's protected least significant difference test, respectively. Pearson correlation coefficients were calculated among all pairings of mean percent healthy and surviving (healthy plus diseased) plants at the final rating, AUDPC, wirestem severity, and percent control weight for each experiment. For field experiments, only data for SP1 (AG-4) were used in the correlations.

\section{RESULTS}

Growth-room experiments. Both the AG-4 and AG-2-1 isolates caused wirestem when introduced into soil as a cornmeal-sand culture or sclerotia. However, there was an interaction ( $F$ significant at $P \leq 0.02$ ) between AG and form of inoculum for percent healthy and surviving plants, wirestem severity, and plant weight

Table 2. Reaction of 12 Brassica oleracea cultivars to Rhizoctonia solani anastomosis group 4 (isolate SP-1) in field plots in 1994

\begin{tabular}{|c|c|c|c|c|c|c|c|}
\hline \multirow[b]{2}{*}{ Crop } & \multirow[b]{2}{*}{ Cultivar } & \multicolumn{3}{|c|}{ Summer } & \multicolumn{3}{|c|}{ Fall } \\
\hline & & \% Healthy & $\%$ Survivors $^{\mathrm{x}}$ & AUDPC $^{\mathbf{y}}$ & \% Healthy & $\%$ Survivors $^{\mathrm{x}}$ & AUDPC $^{\mathbf{y}}$ \\
\hline Cauliflower & $\begin{array}{l}\text { Snowcone } \\
\text { Snow Crown } \\
\text { Arctic }\end{array}$ & $\begin{array}{l}12.5 \mathrm{~d}^{\mathrm{z}} \\
12.5 \mathrm{~d} \\
33.8 \mathrm{a}-\mathrm{c}\end{array}$ & $\begin{array}{l}13.8 \mathrm{~d} \\
20.0 \mathrm{~cd} \\
40.0 \mathrm{a}-\mathrm{c}\end{array}$ & $\begin{array}{l}13.4 \mathrm{a} \\
12.2 \mathrm{a}-\mathrm{c} \\
8.8 \mathrm{~cd}\end{array}$ & $\begin{array}{l}2.5 \mathrm{f} \\
15.0 \mathrm{ef} \\
17.5 \mathrm{~d}-\mathrm{f}\end{array}$ & $\begin{array}{l}48.7 \mathrm{~d} \\
65.0 \mathrm{~cd} \\
91.3 \mathrm{ab}\end{array}$ & $\begin{array}{l}13.0 \mathrm{a} \\
10.6 \mathrm{ab} \\
8.7 \mathrm{bc}\end{array}$ \\
\hline Broccoli & $\begin{array}{l}\text { Packman } \\
\text { Viking } \\
\text { Eureka }\end{array}$ & $\begin{array}{l}15.0 \mathrm{~cd} \\
38.8 \mathrm{ab} \\
32.5 \mathrm{a}-\mathrm{d}\end{array}$ & $\begin{array}{l}23.8 \mathrm{~b}-\mathrm{d} \\
42.5 \mathrm{ab} \\
43.8 \mathrm{ab}\end{array}$ & $\begin{array}{l}12.5 \mathrm{ab} \\
8.1 \mathrm{~d} \\
9.1 \mathrm{~b}-\mathrm{d}\end{array}$ & $\begin{array}{l}26.5 \mathrm{c}-\mathrm{e} \\
26.3 \mathrm{c}-\mathrm{e} \\
37.5 \mathrm{a}-\mathrm{c}\end{array}$ & $\begin{array}{l}87.4 \mathrm{ab} \\
81.3 \mathrm{a}-\mathrm{c} \\
97.5 \mathrm{a}\end{array}$ & $\begin{array}{l}8.7 \mathrm{bc} \\
8.9 \mathrm{bc} \\
5.4 \mathrm{~d}\end{array}$ \\
\hline Cabbage & $\begin{array}{l}\text { Constanza } \\
\text { Little Rock } \\
\text { Bravo }\end{array}$ & $\begin{array}{l}18.8 \mathrm{~b}-\mathrm{d} \\
30.0 \mathrm{a}-\mathrm{d} \\
25.0 \mathrm{~b}-\mathrm{d}\end{array}$ & $\begin{array}{l}25.0 \mathrm{~b}-\mathrm{d} \\
35.0 \mathrm{bc} \\
28.8 \mathrm{~b}-\mathrm{d}\end{array}$ & $\begin{array}{l}12.1 \mathrm{a}-\mathrm{c} \\
10.3 \mathrm{a}-\mathrm{d} \\
11.8 \mathrm{a}-\mathrm{c}\end{array}$ & $\begin{array}{l}35.9 \mathrm{~b}-\mathrm{d} \\
46.3 \mathrm{ab} \\
12.5 \mathrm{ef}\end{array}$ & $\begin{array}{l}91.3 \mathrm{ab} \\
82.5 \mathrm{a}-\mathrm{c} \\
75.0 \mathrm{bc}\end{array}$ & $\begin{array}{r}6.4 \mathrm{~cd} \\
7.4 \mathrm{~cd} \\
11.3 \mathrm{ab}\end{array}$ \\
\hline Collard & $\begin{array}{l}\text { Vates } \\
\text { NC landrace } \\
\text { Blue Max }\end{array}$ & $\begin{array}{l}17.5 \mathrm{~cd} \\
48.8 \mathrm{a} \\
33.8 \mathrm{a}-\mathrm{c}\end{array}$ & $\begin{array}{l}26.3 \mathrm{~b}-\mathrm{d} \\
57.5 \mathrm{a} \\
43.8 \mathrm{ab}\end{array}$ & $\begin{array}{l}11.8 \mathrm{a}-\mathrm{c} \\
7.8 \mathrm{~d} \\
9.1 \mathrm{~b}-\mathrm{d}\end{array}$ & $\begin{array}{l}38.7 \mathrm{a}-\mathrm{c} \\
55.0 \mathrm{a} \\
40.0 \mathrm{a}-\mathrm{c}\end{array}$ & $\begin{array}{l}86.3 \mathrm{ab} \\
91.3 \mathrm{ab} \\
88.7 \mathrm{ab}\end{array}$ & $\begin{array}{l}6.8 \mathrm{~cd} \\
5.5 \mathrm{~d} \\
7.5 \mathrm{~cd}\end{array}$ \\
\hline $\mathrm{LSD}_{0.05}$ & & 20.5 & 21.0 & 3.5 & 18.7 & 18.7 & 2.8 \\
\hline
\end{tabular}

${ }^{\mathrm{x}}$ Percent surviving plants at harvest $=$ (number of healthy + number of diseased plants)/(total number of plants).

y Area under the disease progress curve, calculated from disease incidence ratings.

${ }^{\mathrm{z}}$ Means within a column followed by the same letter are not significantly different according to Fisher's protected least significant difference test, $\alpha=0.05$. 
(Fig. 1). Based on all four measurements, wirestem was less severe when sclerotia of isolate RB1 (AG-2-1) were used as inoculum compared to a cornmeal-sand culture of RB1 (least squares means $t$ tests, $P=$ 0.0001). Likewise, with sclerotia as the source of inoculum for both isolates, RB1 was less virulent than isolate SP1 (AG-4) $(P=0.0001)$. Control plants growing in noninfested soil remained free of wirestem symptoms and had higher fresh weights than inoculated plants.

No interaction between cultivar and AG or inoculum was observed. Thus, cultivar means across all four treatments were used to examine the reaction of $B$. oleracea cultivars to $R$. solani. Blue Max collard had lower wirestem severity and higher plant weight as a percentage of control weight than did the other 11 cultivars (Fisher's protected least significant difference test, $\alpha=0.05$ ) (Table 1). In addition, significantly more Blue Max plants survived until seedling harvest than did Snow Crown and Snowcone cauliflower plants. Cv. Arctic cauliflower also was significantly less diseased than the other two cauliflower cultivars. At seedling harvest, all cultivars averaged $\geq 70 \%$ diseased plants, i.e., plants with visible foliar symptoms (Fig. 2).

Field experiments. The two experiments conducted during the summer and fall of 1994 included both RB1 and SP1 applied at 50 sclerotia per $\mathrm{kg}$ of soil. Wirestem was severe with isolate SP1 (Table 2), whereas disease was nearly absent on plants inoculated with RB1, which made it impossible to detect differences among cultivars in either experiment with the latter isolate. Percent healthy plants at 20 days after inoculation was $\leq 55 \%$ in both experiments. With SP1 inoculation, Blue Max collard and the North Carolina (NC) collard landrace had a greater percentage of healthy and surviving plants than did Snowcone and Snow Crown cauliflower in both experiments. The collard landrace also had lower AUDPC values than these two cauliflower cultivars in both experiments, whereas Blue Max collard had a lower AUDPC than Snowcone cauliflower in both experiments. Arctic cauliflower had a greater percentage of surviving plants and a lower AUDPC than did Snowcone cauliflower in both experiments. $\mathrm{Cv}$. Viking broccoli had a greater percentage of healthy plants at harvest than did cv. Packman broccoli in the summer experiment. The reactions of other cultivars generally were intermediate compared to the cauliflower and collard entries mentioned above and varied between these two experiments.

Because of the severe wirestem in the experiments conducted in 1994, the inoculum density of isolate SP1 was lowered to 25 sclerotia per $\mathrm{kg}$ of soil in 1995 and 1996. Isolate RB1 was not evaluated because no disease was observed with this isolate in the previous two field trials. As in 1994, Blue Max collard and the NC collard landrace had a greater percentage of healthy and surviving plants and lower AUDPC values and wirestem severity than did Snowcone cauliflower in both experiments (Tables 3 and 4). In addition, Viking broccoli and Tendergreen mustard also were significantly less diseased than Snowcone

based on all four measurements. Blue Max, Viking, and Tendergreen also had a greater percentage of healthy plants at harvest and a lower AUDPC value than Snow Crown cauliflower. Arctic cauliflower had a higher percentage of healthy and surviving plants and less wirestem severity than the other

Table 3. Reaction of 12 Brassica oleracea cultivars and $1 \mathrm{~B}$. perviridis cultivar ${ }^{\mathrm{t}}$ to Rhizoctonia solani anastomosis group 4 in field plots during the fall of 1995

\begin{tabular}{llccccc}
\hline Crop & Cultivar & \% Healthy & \% Survivors & AUDPC & $\begin{array}{c}\text { Wirestem }^{\mathbf{u}} \\
\text { severity }^{\mathbf{w}}\end{array}$ & $\begin{array}{c}\text { \% Control } \\
\text { weight }^{\mathbf{x}}\end{array}$ \\
\hline Cauliflower & Snowcone & $34.3 \mathrm{c}^{\mathrm{y}}$ & $83.4 \mathrm{c}$ & $5.7 \mathrm{ab}$ & $6.3 \mathrm{a}$ & 63.5 \\
& Snow Crown & $36.3 \mathrm{c}$ & $87.5 \mathrm{bc}$ & $5.6 \mathrm{a}-\mathrm{c}$ & $5.7 \mathrm{a}-\mathrm{d}$ & 48.2 \\
& Arctic & $62.5 \mathrm{a}$ & $97.5 \mathrm{a}$ & $3.4 \mathrm{de}$ & $4.5 \mathrm{ef}$ & 83.1 \\
Broccoli & Packman & $37.5 \mathrm{c}$ & $97.5 \mathrm{a}$ & $5.9 \mathrm{a}$ & $5.9 \mathrm{ab}$ & 48.2 \\
& Viking & $66.3 \mathrm{a}$ & $98.8 \mathrm{a}$ & $2.9 \mathrm{e}$ & $4.1 \mathrm{fg}$ & 52.9 \\
& Eureka & $63.8 \mathrm{a}$ & $95.0 \mathrm{ab}$ & $3.4 \mathrm{de}$ & $4.4 \mathrm{fg}$ & 66.7 \\
Cabbage & Constanza & $48.8 \mathrm{a}-\mathrm{c}$ & $91.3 \mathrm{a}-\mathrm{c}$ & $4.8 \mathrm{a}-\mathrm{d}$ & $5.6 \mathrm{a}-\mathrm{e}$ & 42.4 \\
& Little Rock & $38.8 \mathrm{bc}$ & $93.8 \mathrm{ab}$ & $6.4 \mathrm{a}$ & $5.9 \mathrm{a}-\mathrm{c}$ & 40.5 \\
& Bravo & $57.0 \mathrm{ab}$ & $91.2 \mathrm{a}-\mathrm{c}$ & $4.2 \mathrm{~b}-\mathrm{e}$ & $5.1 \mathrm{~b}-\mathrm{f}$ & 52.7 \\
Collard & Vates & $60.0 \mathrm{a}$ & $98.8 \mathrm{a}$ & $4.0 \mathrm{c}-\mathrm{e}$ & $4.9 \mathrm{c}-\mathrm{f}$ & 44.5 \\
& NC landrace & $61.3 \mathrm{a}$ & $95.0 \mathrm{ab}$ & $3.7 \mathrm{de}$ & $4.6 \mathrm{ef}$ & 55.2 \\
& Blue Max & $60.0 \mathrm{a}$ & $96.3 \mathrm{ab}$ & $3.8 \mathrm{de}$ & $4.8 \mathrm{~d}-\mathrm{f}$ & 72.5 \\
\multirow{2}{*}{ Mustard } & Tendergreen & $67.5 \mathrm{a}$ & $92.5 \mathrm{ab}$ & $2.9 \mathrm{e}$ & $3.4 \mathrm{~g}$ & 59.8 \\
LSD $_{0.05}$ & & 18.8 & 8.9 & 1.6 & 1.1 & $\mathrm{NS}^{\mathrm{z}}$ \\
\hline
\end{tabular}

${ }^{\mathrm{t}}$ Mustard cv. Tendergreen.

${ }^{u}$ Percent surviving plants at harvest $=$ (number of healthy + number of diseased plants)/(total number of plants).

${ }^{v}$ Area under the disease progress curve, calculated from disease incidence ratings.

${ }^{\mathrm{w}}$ Wirestem severity at harvest was rated on a scale of 1 to 10 , where $1=$ no disease and $10=$ plant completely rotted.

${ }^{\mathrm{x}}$ Percent control weight $=$ weight of inoculated plants in each replication/mean weight of noninoculated plants of the same cultivar across replications.

${ }^{y}$ Means within a column followed by the same letter are not significantly different according to Fisher's protected least significant difference test, $\alpha=0.05$.

${ }^{\mathrm{z}}$ Not significantly different.

Table 4. Reaction of 12 Brassica oleracea cultivars and 1 B. perviridis cultivar ${ }^{t}$ to Rhizoctonia solani anastomosis group 4 in field plots during the spring of 1996

\begin{tabular}{|c|c|c|c|c|c|c|}
\hline Crop & Cultivar & \% Healthy & \% Survivors ${ }^{\mathrm{u}}$ & AUDPC $^{\mathbf{v}}$ & $\begin{array}{l}\text { Wirestem } \\
\text { severity }^{w}\end{array}$ & $\begin{array}{c}\text { \% Control } \\
\text { weight }^{x}\end{array}$ \\
\hline Cauliflower & $\begin{array}{l}\text { Snowcone } \\
\text { Snow Crown } \\
\text { Arctic }\end{array}$ & $\begin{array}{l}51.3 \mathrm{e}^{\mathrm{y}} \\
75.0 \mathrm{~cd} \\
72.5 \mathrm{~d}\end{array}$ & $\begin{array}{l}83.7 \mathrm{e} \\
90.0 \mathrm{~d} \\
96.3 \mathrm{a}-\mathrm{c}\end{array}$ & $\begin{array}{l}3.02 \mathrm{a} \\
1.23 \mathrm{~b} \\
1.33 \mathrm{ab}\end{array}$ & $\begin{array}{l}5.0 \mathrm{a} \\
3.4 \mathrm{bc} \\
3.5 \mathrm{~b}\end{array}$ & $\begin{array}{l}64.5 \mathrm{f} \\
74.8 \mathrm{~d}-\mathrm{f} \\
82.7 \mathrm{c}-\mathrm{f}\end{array}$ \\
\hline Broccoli & $\begin{array}{l}\text { Packman } \\
\text { Viking } \\
\text { Eureka }\end{array}$ & $\begin{array}{l}81.3 \mathrm{~b}-\mathrm{d} \\
97.5 \mathrm{a} \\
87.5 \mathrm{a}-\mathrm{c}\end{array}$ & $\begin{array}{l}98.7 \mathrm{ab} \\
97.5 \mathrm{a}-\mathrm{c} \\
92.5 \mathrm{~cd}\end{array}$ & $\begin{array}{l}1.03 \mathrm{~b} \\
0.064 \mathrm{c} \\
0.90 \mathrm{~b}\end{array}$ & $\begin{array}{l}3.1 \mathrm{bc} \\
2.3 \mathrm{c}-\mathrm{e} \\
3.0 \mathrm{bc}\end{array}$ & $\begin{array}{l}69.3 \mathrm{ef} \\
109.5 \mathrm{a} \\
82.5 \mathrm{c}-\mathrm{f}\end{array}$ \\
\hline Cabbage & $\begin{array}{l}\text { Constanza } \\
\text { Little Rock } \\
\text { Bravo }\end{array}$ & $\begin{array}{l}82.5 \mathrm{~b}-\mathrm{d} \\
83.7 \mathrm{~b}-\mathrm{d} \\
88.7 \mathrm{ab}\end{array}$ & $\begin{array}{c}96.3 \mathrm{a}-\mathrm{c} \\
100.0 \mathrm{a} \\
96.3 \mathrm{a}-\mathrm{c}\end{array}$ & $\begin{array}{l}1.22 \mathrm{~b} \\
0.76 \mathrm{~b} \\
0.87 \mathrm{~b}\end{array}$ & $\begin{array}{l}2.7 \mathrm{~b}-\mathrm{d} \\
3.1 \mathrm{~b}- \\
2.9 \mathrm{~b}-\mathrm{d}\end{array}$ & $\begin{array}{l}90.0 \mathrm{~b}-\mathrm{d} \\
85.0 \mathrm{c}-\mathrm{e} \\
107.4 \mathrm{ab}\end{array}$ \\
\hline Collard & $\begin{array}{l}\text { Vates } \\
\text { NC landrace } \\
\text { Blue Max }\end{array}$ & $\begin{array}{l}83.7 \mathrm{~b}-\mathrm{d} \\
91.3 \mathrm{ab} \\
97.5 \mathrm{a}\end{array}$ & $\begin{array}{l}93.7 \mathrm{~b}-\mathrm{d} \\
98.7 \mathrm{ab} \\
100.0 \mathrm{a}\end{array}$ & $\begin{array}{l}1.26 \mathrm{~b} \\
0.46 \mathrm{bc} \\
0.044 \mathrm{c}\end{array}$ & $\begin{array}{l}3.0 \mathrm{bc} \\
2.3 \mathrm{c}-\mathrm{e} \\
1.8 \mathrm{de}\end{array}$ & $\begin{array}{l}95.4 \mathrm{a}-\mathrm{c} \\
85.4 \mathrm{c}-\mathrm{e} \\
93.4 \mathrm{a}-\mathrm{d}\end{array}$ \\
\hline Mustard & Tendergreen & $98.7 \mathrm{a}$ & $98.7 \mathrm{ab}$ & $0.030 \mathrm{c}$ & $1.3 \mathrm{e}$ & $94.9 \mathrm{a}-\mathrm{c}$ \\
\hline $\mathrm{LSD}_{0.05}$ & & 13.7 & 6.2 & $\ldots^{\mathrm{z}}$ & 1.1 & 18.7 \\
\hline
\end{tabular}

${ }^{\mathrm{t}}$ Mustard cv. Tendergreen.

u Percent surviving plants at harvest $=$ (number of healthy + number of diseased plants)/(total number of plants).

${ }^{v}$ Area under the disease progress curve, calculated from disease incidence ratings.

${ }^{\mathrm{w}}$ Wirestem severity at harvest was rated on a scale of 1 to 10 , where $1=$ no disease and $10=$ plant completely rotted.

${ }^{\mathrm{x}}$ Percent control weight $=$ weight of inoculated plants in each replication/mean weight of noninoculated plants of the same cultivar across replications.

${ }^{y}$ Means within a column followed by the same letter are not significantly different according to Fisher's protected least significant difference test, $\alpha=0.05$.

${ }^{\mathrm{z}}$ AUDPC was transformed by calculating the square root before analysis of variance; values shown are back-transformed means. 
two cauliflower cultivars. In the 1995 and 1996 experiments, Viking broccoli had a greater percentage of healthy plants at harvest than did Packman broccoli. Weight of inoculated plants was significantly reduced compared to noninoculated plants in 1995 but not in 1996 . plants was correlated negatively with the wirestem severity rating in the growth room (Table 5) and the 1995 and 1996 field experiments (Table 6). Conversely, disease incidence (percent diseased and dead plants) was always correlated positively with severity in all environments. In addition, percent healthy plants at harvest was correlated negatively with AUDPC in the two 1994 field studies $(r=-0.96$ and -0.91 , $P=0.0001$ for the summer and fall experiments, respectively) and in 1995 and 1996 cent control weight) was highly correlated with the three disease measurements used in the growth-room experiment (Table 5), but only with AUDPC in the 1996 field experiment (Table 6).

In all four field experiments, the percentage of plants with wirestem symptoms (percent diseased and dead plants) increased significantly over time (Fig. 3). During the summer of 1994 and the spring of 1996, mean wirestem incidence for all cultivars
Evaluation of criteria. Percent healthy (Table 6). Plant weight (expressed as per-

plateaued at 10 and 14 days after transplanting, respectively (Helmert contrasts for time, $F$ significant at $P \leq 0.01$ ), whereas incidence increased during the entire 19- to 20-day experiments during the fall of 1994 and the fall of 1995. Although disease incidence for individual cultivars also increased during the 3-week rating period ( $F$ significant at $P \leq 0.05$ ), relative rankings of cultivars stabilized by 8 days after transplanting. In all four experiments, the first visual assessment of wirestem at 3 to 5 days after transplanting was significantly lower than the mean of the four subsequent assessments. In general, cultivar rankings based on the second reading at 7 to 8 days after transplanting did not differ from the mean of the three subsequent readings (Helmert contrasts for time by cultivar, $F$ significant at $P \leq 0.05$ ). Likewise, the third and fourth readings did not differ significantly from subsequent readings. To test this stabilization of cultivar reaction further, differences among cultivars at the second ( 7 or 8 days) and fifth (16 to 20 days) readings were compared. In the summer of 1994, fall of 1994, fall of 1995 , and spring of 1996 experiments, 4 of 5,8 of 9,6 of 6 , and 10 of 10 cultivars, respectively, that had significantly more healthy plants than Snowcone cauliflower at the second reading also had significantly more healthy

Table 5. Correlation of criteria used to measure the reaction of Brassica oleracea cultivars to Rhizoctonia solani anastomosis groups 2-1 and 4 in growth-room experiments

\begin{tabular}{lcccc}
\hline & \% Healthy & \% Survivors & Severity & \% Control weight \\
\hline \% Healthy & $1.0000^{\mathrm{y}}$ & 0.7533 & -0.8195 & 0.8576 \\
& $0.0000^{\mathrm{z}}$ & 0.0047 & 0.0011 & 0.0004 \\
\% Survivors & $\ldots$ & 1.0000 & -0.9528 & 0.8699 \\
& $\ldots$ & 0.0000 & 0.0001 & 0.0002 \\
Severity & $\ldots$ & $\ldots$ & 1.0000 & -0.9277 \\
& $\ldots$ & $\ldots$ & 0.0000 & 0.0001 \\
\% Control weight & $\ldots$ & $\ldots$ & $\ldots$ & 1.0000 \\
& $\ldots$ & $\ldots$ & $\ldots$ & 0.0000 \\
\hline
\end{tabular}

y Pearson correlation coefficient for the paired parameters.

${ }^{\mathrm{z}}$ Probability of a greater absolute value of the correlation coefficient directly above.

Table 6. Correlation of parameters used to measure the reaction of Brassica oleracea and B. perviridis cultivars to Rhizoctonia solani anastomosis group 4 in field experiments conducted during the fall of 1995 (top half of matrix, above diagonal) and the spring of 1996 (bottom half of matrix, below diagonal).

\begin{tabular}{lccccc}
\hline & \% Healthy & \% Survivors & AUDPC $^{\mathbf{x}}$ & Severity & $\begin{array}{c}\text { \% Control } \\
\text { weight }\end{array}$ \\
\hline \% Healthy & $\ldots$ & $0.5793^{\mathrm{y}}$ & -0.9736 & -0.9372 & 0.42881 \\
& $\ldots$ & $0.0380^{\mathrm{z}}$ & 0.0001 & 0.0001 & 0.1437 \\
\% Survivors & 0.8015 & $\ldots$ & -0.4719 & -0.4899 & 0.08962 \\
& 0.0010 & $\ldots$ & 0.1035 & 0.0892 & 0.7709 \\
AUDPC & -0.7078 & -0.6356 & $\ldots$ & 0.9398 & -0.49932 \\
& 0.0068 & 0.0196 & $\ldots$ & 0.0001 & 0.0823 \\
Severity & -0.6670 & -0.5594 & 0.9485 & $\ldots$ & -0.39290 \\
& 0.0128 & 0.0468 & 0.0001 & $\ldots$ & 0.1842 \\
\% Control weight & 0.5920 & 0.4185 & -0.7139 & -0.6425 & $\ldots$ \\
& 0.0330 & 0.1547 & 0.0061 & 0.0179 & $\ldots$ \\
\hline
\end{tabular}

${ }^{x}$ Area under the disease progress curve, calculated from disease incidence ratings.

y Pearson correlation coefficient for the paired parameters.

${ }^{\mathrm{z}}$ Probability of a greater absolute value of the correlation coefficient directly above. plants at harvest (fifth reading) (Fig. 3). In addition, the percentage of healthy plants at the second reading was as highly or more highly correlated with AUDPC and wirestem severity as the percentage of healthy plants at the fifth reading (data not shown).

\section{DISCUSSION}

The overall goal of this research was to establish criteria that breeders and pathologists might use in screening $B$. oleracea germ plasm in growth-room or field tests for resistance to $R$. solani. In growth-room tests, cultivars of $B$. oleracea reacted similarly to both cornmeal-sand inoculum and sclerotia. Although wirestem symptoms appeared more rapidly in plants inoculated with cornmeal-sand than with sclerotia, cultivar reactions after 2 weeks were parallel for the two forms of inoculum. Because the type of inoculum did not influence cultivar evaluation significantly, we chose to continue more extensive field evaluations with only inoculation with sclerotia, which could be accomplished more readily than inoculation with cornmeal-sand. McCoy and Kraft (18) also concluded that sclerotia were the preferred inoculum for screenings. In their study, rankings of 20 pea cultigens for resistance to stem rot differed when cornmeal-sand cultures or sclerotia of $R$. solani AG-4 were used as inoculum in greenhouse tests. Soil inoculum density was more reproducible with sclerotia than with cornmeal-sand, because growth of different $R$. solani isolates varied on cornmeal-sand (18). Ester and Gerlagh (8) concluded that screening radish for resistance to $R$. solani was better done in the field in naturally infested soil than in laboratory or growthroom tests. In Japanese sugar beet fields, overwintered viable sclerotia of $R$. solani AG-2-2 were a more effective source of inoculum than infested plant debris (14). Our field tests with sclerotia as a source of inoculum approximated naturally infested soil and provided consistent results, regardless of the level of inoculum or the time of year when the test was initiated.

Few studies have examined the reaction of $B$. oleracea to more than one AG of $R$. solani (27). In the growth room, where cornmeal-sand inoculum of both the AG-2-1 and AG-4 isolates caused severe wirestem, no differences in cultivar reaction between the two AGs were observed. Likewise, with sclerotial inoculum, even though the degree of wirestem was greater with the AG-4 isolate than with the AG-2-1 isolate, there was no interaction of cultivar and isolate. The lack of specificity in the reaction of $B$. oleracea cultivars to the two predominant AGs attacking this species is fortuitous. Relative resistance to one $\mathrm{AG}$ appears to be effective against the other AG as well.

The faster growing AG-4 may cause more wirestem losses in the southeastern United States than AG-2-1. The lack of wirestem 
development with AG-2-1 in our field tests tends to support this hypothesis. AG-4 was more virulent on canola than AG-2-1 at 26 to $35^{\circ} \mathrm{C}$ in controlled-temperature tests $(31)$ but also was recovered from diseased canola seedlings in Georgia during the winter (2). The mean growth rate of AG-4 at $18^{\circ} \mathrm{C}$ was reported to be $0.51 \mathrm{~mm} / \mathrm{h}$, whereas for AG-2-1 it was reported to be $0.34 \mathrm{~mm} / \mathrm{h}$ (15). For our experiments, sclerotia of both AGs were produced on autoclaved green beans. Prior nutrition of the sclerotia likely was not responsible for the differences in virulence. Currently, we are comparing a number of AG-4 and AG-2-1 isolates for their potential to cause wirestem in $B$. oleracea to provide more conclusive evidence about their relative virulence.

We evaluated host response to inoculation with $R$. solani by several criteria to determine which individual criterion might provide a consistent measure of relative susceptibility or resistance to wirestem, while at the same time providing a costeffective means of comparing a large number of B. oleracea entries. Our criteria can be divided into three groups: visual assessments of foliar symptoms, severity of symptoms on hypocotyl and roots, and weight of inoculated plants as a percentage of noninoculated plant weights. The most direct indicator of wirestem was the disease severity rating, an assessment of primary symptoms at the site of infection. The other four criteria indirectly measured wirestem by assessing plant mortality or reduced growth. In general, criteria based on foliar wirestem symptoms, i.e., percent healthy plants, percent surviving plants, and AUDPC, were correlated highly with severity but were not consistently correlated with weight as a percentage of control. Percent healthy plants and AUDPC (calculated from percent diseased and dead plants) were more highly correlated with wirestem severity than was percent surviving plants. In another study, incidence and severity of blackleg on canola (B. napus) also were highly correlated (4). Although percent healthy plants and percent survivors were single measurements taken at one point (transplant harvest) in the epidemic, they were as informative as AUDPC, which integrated percent diseased plants over the course of the epidemic. All three criteria were much easier to evaluate than disease severity, yet they separated the most susceptible entries from those that were significantly less susceptible. Plant weight, expressed as a percentage of control to account for different growth rates among different crops and cultivars, is influenced by factors other than wirestem, so we expected that the weight of field-grown plants would not be the most sensitive criterion to compare cultivar reactions. Disease severity was the most difficult criterion to apply because it required digging up plants and washing roots before rating. Percent healthy plants is readily assessed and does not require destructive sampling of plants, which is particularly important with $B$. oleracea entries, which often are from highly heterogeneous and heterozygous populations. The standard procedure with such populations is to identify resistant selections, remove them from the field, and perform controlled pollinations in an insect-free environment. Destructive sampling would prohibit this, whereas assessment of percent healthy plants would be very compatible with the usual selection process.

If a primary goal is to compare entries for relative susceptibility or resistance to wirestem, the optimal time to evaluate stable disease incidence and compare cultivars in field trials is 10 to 14 days after inoculation with $R$. solani. In all of our experiments, relative rankings of cultivars, based on disease incidence (percent diseased and dead plants), stabilized at 8 days after inoculation. Although disease incidence increased beyond 14 days after inoculation in the fall of 1994 and the fall of 1995 studies, the increases were much smaller than those occurring before 14 days; overall, disease incidence plateaued for most entries, except the most susceptible (Fig. 3). Disease incidence also reached a plateau with AG-4 isolate SP1 in a previous study (17). If disease severity is the criterion chosen to compare entries, making these observations during the 14- to 20-day period is critical, because after this time plants will be too large to dig up and rate based on the scale used in the current study.

The number of $B$. oleracea cultivars evaluated in these experiments was lim- ited. Initially, we did not expect to observe dramatic differences in response to $R$. $s o$ lani inoculation among a relatively small group of lines. However, the significant differences observed among lines in the first tests were observed repeatedly throughout the course of the study. In our comparisons across all crop groups, a consistent differential was established between the most susceptible cultivar, Snowcone cauliflower, and the least susceptible cultivar, Blue Max collard. In all tests, nearly all criteria separated these two entries. In addition, Snow Crown cauliflower and the NC collard landrace (9) also showed consistently different disease levels in the field. Snow Crown typically exhibited high levels of disease, whereas the landrace performed much like Blue Max. Blue Max collard (B. oleracea) was as resistant as Tendergreen mustard ( $B$. perviridis). Kataria et al. (16) proposed that the Brassica $c$ genome of $B$. oleracea is responsible for the greater susceptibility of this species to $R$. solani AG-2-1 than other Brassica spp. However, only one botanical group of $B$. oleracea, kale, was evaluated in that study. We found kale to be more susceptible to $R$. solani AG-2-1 than other botanical groups of B. oleracea (A. P. Keinath and M. W. Farnham, unpublished data). Collard, which is native to the southeastern United States, often is grown during the summer, when environmental conditions favor infection by $R$. solani. It is possible that the moderate level of resistance in collard represents an adaptation to survival in the presence of indigenous $R$. solani.

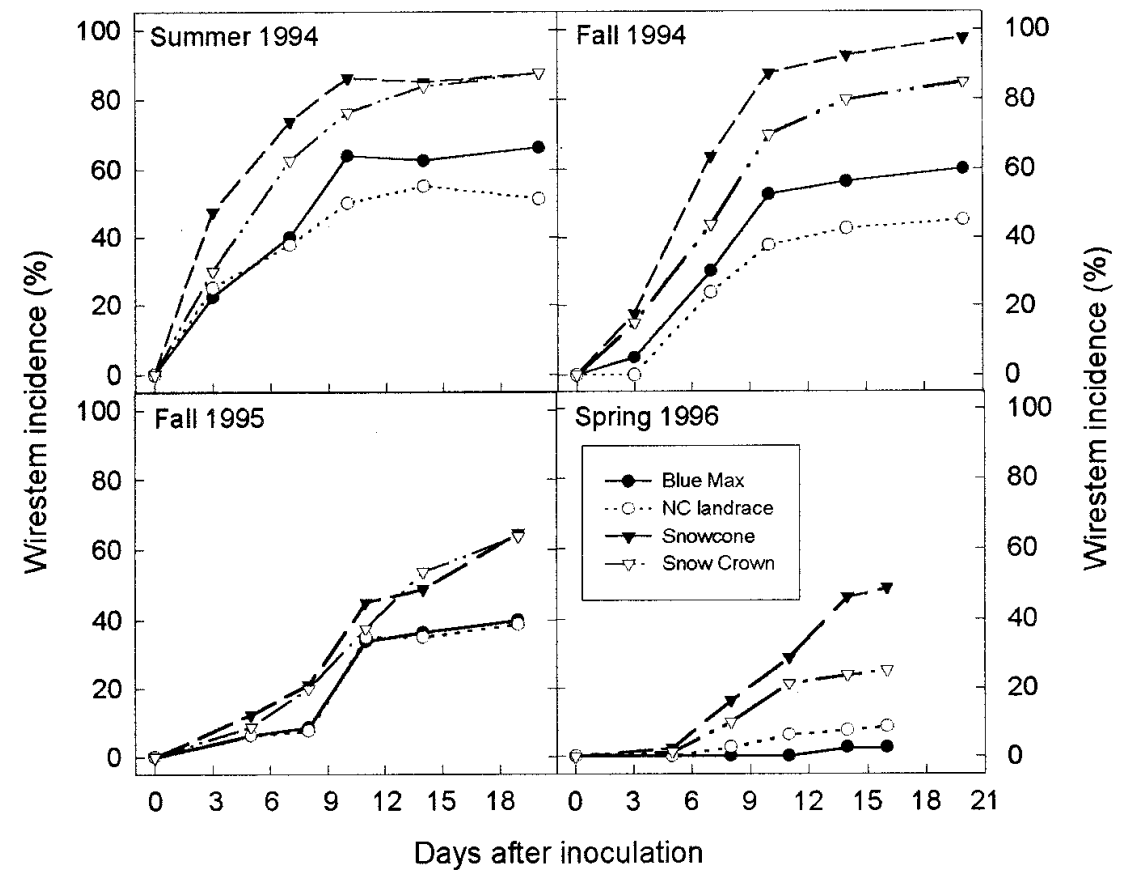

Fig. 3. Wirestem progression (percent diseased and dead plants) on susceptible cauliflower (cvs. Snowcone and Snow Crown) and moderately resistant collard (cvs. Blue Max and a NC landrace) plants in field tests. Seedlings were inoculated with 50 (1994) or 25 (1995 and 1996) sclerotia of Rhizoctonia solani anastomosis group 4 per $\mathrm{kg}$ of soil. Each data point is the mean of four replications. 
The two most susceptible cultivars were both cauliflower, whereas the two least diseased cultivars were collard. Cauliflower has been reported previously to be relatively susceptible to wirestem (7). However, because of significant differences among cultivars within crops, no one crop was more susceptible than another. The cauliflower, collard, and broccoli groups all had one cultivar that often was more resistant (Arctic cauliflower and Viking broccoli) or susceptible (Vates collard) than the other two cultivars in the group. Apparently, differences in susceptibility to $R$. solani within $B$. oleracea botanical groups are as great as differences between groups. Farnham (9) has shown that genetic variation within a $B$. oleracea botanical group is often as great as variation between groups. Sampling a wider array of germ plasm from any one crop group may identify different individuals with a higher level of resistance (or reduced susceptibility) than was observed in the current study. The moderately resistant cvs. Arctic cauliflower, Blue Max collard, and Viking broccoli should perform better than more susceptible cultivars where wirestem reduces transplant survival.

Based on our results, B. oleracea seedlings transplanted into field plots infested with $R$. solani AG-4 sclerotia could be evaluated effectively for relative wirestem susceptibility by simply determining the number of healthy survivors at 2 to 3 weeks after inoculation. As an alternative, several readings of healthy and diseased or dead plants per entry during the 2 to 3 weeks after inoculation would allow one to compute AUDPC values and measure disease incidence over time as well as the rate at which disease progressed. By including differential checks (e.g., cvs. Snowcone and Blue Max) with previously unevaluated germ plasm, cole crop researchers can effectively screen a collection of entries and possibly identify high levels of resistance to $R$. solani.

\section{ACKNOWLEDGMENTS}

We thank E. Gomperts, G. DuBose, W. May III, Y. Alston, and R. Davis for excellent technical assistance.

\section{LITERATURE CITED}

1. Acharya, S. N., Verma, P. R., Dueck, J., and Downey, R. K. 1984. Screening rapeseed/ canola for resistance to damping-off and seedling root rot caused by Rhizoctonia solani.
Can. J. Plant Pathol. 6:325-328.

2. Baird, R. E. 1996. First report of Rhizoctonia solani AG-4 on canola in Georgia. Plant Dis. 80:104.

3. Bandoni, R. J. 1979. Safranin as a rapid nuclear stain for fungi. Mycologia 71:873-874.

4. Bansal, V. K., Kharbanda, P. D., Stringam, G. R., Thiagarajah, M. R., and Tewari, J. P. 1994. A comparison of greenhouse and field screening methods for blackleg resistance in doubled haploid lines of Brassica napus. Plant Dis. 78:276-281.

5. Butler, E. E. 1980. A method for long-time culture storage of Rhizoctonia solani. Phytopathology 70:820-821.

6. Campbell, C. L. 1986. Interpretation and uses of disease progress curves for root diseases. Pages 38-54 in: Plant Disease Epidemiology, Vol. 1, Population Dynamics and Management. K. J. Leonard and W. E. Fry, eds. Macmillan Publishing Co., New York.

7. D'Ercole, N. 1974. Prove di suscettibilità varietale del cavolfiore all'infezione di Rhizoctonia solani Kühn in serra. Inf. Fitopatol. 6: 11-12.

8. Ester, A., and Gerlagh, M. 1986. Onderzoek naar een snelle en betrouwbare toetsmethode voor resistentie tegen Rhizoctonia in radijs leidde niet tot resultaat. (Attempt to find a rapid and reliable method of testing for resistance to Rhizoctonia in radish was unsuccessful.) Zaadbelangen 40:49-51.

9. Farnham, M. W. 1996. Genetic variation among and within United States collard cultivars and landraces as determined by randomly amplified polymorphic DNA markers. J. Am. Soc. Hortic. Sci. 121:374-379.

10. Farnham, M. W., and Keinath, A. P. 1996. Development of strategies to evaluate Brassica oleracea $\mathrm{L}$. vegetable crops for wirestem caused by Rhizoctonia solani. (Abstr.) HortScience 31:621.

11. Gratz, L. O. 1925. Wire stem of cabbage. NY State Agricultural Experiment Station Memoir 85.

12. Gugel, R. K., Yitbarek, S. M., Verma, P. R., Morrall, R. A. A., and Sadasivaiah, R. S. 1987. Etiology of the Rhizoctonia root rot complex of canola in the Peace River region of Alberta. Can. J. Plant Pathol. 9:119-128.

13. Howard, R. J., and Williams, P. H. 1976. Methods for detecting resistance to Pythium and Rhizoctonia root diseases in seedling carrots. Plant Dis. Rep. 60:151-156.

14. Hyakumachi, M., and Ui, T. 1982. The role of the overwintered plant debris and sclerotia as inoculum in the field following sugar beet root rot. Ann. Phytopathol. Soc. Jpn. 48:628633.

15. Kaminski, D. A., and Verma, P. R. 1985. Cultural characteristics, virulence and in vitro temperature effect on mycelial growth of Rhizoctonia isolates from rapeseed. Can. J. Plant Pathol. 7:256-261.

16. Kataria, H. R., Verma, P. R., and Rakow, G. 1993. Fungicidal control of damping-off and seedling root rot in Brassica species caused by Rhizoctonia solani in the growth chamber Ann. Appl. Biol. 123:247-256.

17. Keinath, A. P. 1995. Relationships between inoculum density of Rhizoctonia solani, wirestem incidence and severity, and growth of cabbage. Phytopathology 85:1487-1492.

18. McCoy, R. J., and Kraft, J. M. 1984. Comparison of techniques and inoculum sources in evaluating peas (Pisum sativum) for resistance to stem rot caused by Rhizoctonia solani. Plant Dis. 68:53-55.

19. Mihuta-Grimm, L., and Rowe, R. C. 1986 Trichoderma spp. as biocontrol agents of Rhizoctonia damping-off of radish in organic soil and comparison of four delivery systems. Phytopathology 76:306-312.

20. Ogoshi, A. 1987. Ecology and pathogenicity of anastomosis and intraspecific groups of Rhizoctonia solani Kühn. Annu. Rev. Phytopathol. 25:125-143.

21. SAS Institute Inc. 1988. SAS/STAT User's Guide. Release 6.03 edition. SAS Institute Inc., Cary, NC.

22. Shaner, G., and Finney, R. E. 1977. The effect of nitrogen fertilization on the expression of slow-mildewing resistance in Knox wheat. Phytopathology 67:1051-1056.

23. Shephard, M. C., and Wood, R. K. S. 1963. The effect of environment and nutrition of pathogen and host in the damping-off of seedlings by Rhizoctonia solani. Ann. Appl. Biol. 51:389-402.

24. Smith, J. P. 1995. Reactions of thirteen cabbage cultivars to black rot and wirestem, 1991 Biol. Cult. Tests 10:130.

25. Smith, J. P., and Keinath, A. P. 1995. Effects of wounding, transplant type, and planting depth on the incidence of wirestem, 1993. Biol. Cult. Tests 10:131.

26. Steel, R. G. D., and Torrie, J. H. 1980. Principles and Procedures of Statistics. 2nd ed. McGraw-Hill Book Co., New York.

27. Sumner, D. R. 1974. Ecology and control of seedling diseases of crucifers. Phytopathology 64:692-697.

28. van Bruggen, A. H. C., and Arneson, P. A. 1985. A quantifiable type of inoculum of Rhizoctonia solani. Plant Dis. 69:966-969.

29. Williams, P. H. 1985. Crucifer Genetics Cooperative Resource Book. University of Wisconsin, Madison.

30. Yang, J., Verma, P. R., and Lees, G. L. 1992. The role of cuticle and epidermal cell wall in resistance of rapeseed and mustard to Rhizoctonia solani. Plant Soil 142:315-321.

31. Yitbarek, S. M., Verma, P. R., Gugel, R. K., and Morrall, R. A. A. 1988. Effect of soil temperature and inoculum density on pre-emergence damping-off of canola caused by Rhizoctonia solani. Can. J. Plant Pathol. 10: 93-98.

32. Yitbarek, S. M., Verma, P. R., and Morrall, R. A. A. 1987. Anastomosis groups, pathogenicity, and specificity of Rhizoctonia solani isolates from seedling and adult rapeseed/canola plants and soils in Saskatchewan. Can. J. Plant Pathol. 9:6-13. 